\title{
В КНУБА ЗАПОЧАТКОВАНО МІЖНАРОДНУ НАУКОВО-ПРАКТИЧНУ КОНФЕРЕНЦІЮ «ПІДВОДНІ ТЕХНОЛОГІЇ»
}

\author{
Михайло Сукач \\ Київський національний університет будівництва і архітектури \\ Повітрофрлотський просп, 31, Київ, Україна, 03037, e-mail: msukach@ua.fm \\ INTERNATIONAL SCIENTIFICALLY-PRACTICAL CONFERENCE
}

Mykhailo Sukach

Kyiv National University of Construction and Architecture

Povitroflotsky prosp., 31, Kyiv, Ukraine, 03037, e-mail: msukach@ua.fm

В травні поточного року відбулася Перша Міжнародна науково-практична конференція «Підводні технології, 2015», яку присвячено глобальному впливу води на життя та інноваційні технології. Проблематика форуму, що зібрався на теренах Київського національного університету будівництва і архітектури: моніторинг та дослідження акваторій, видобування корисних копалин, у тому числі 3 альтернативних джерел, гідротехнічне будівництво і архітектура споруд, механізація і автоматизація технологічних процесів, інженерія підводних робіт, енергетичне та інформаційне забезпечення, транспортування й логістика, біоресурси та екологія водного середовища.

Організаторами конференції виступили Міністерство освіти і науки України, Київський національний університет будівництва i архітектури, Польська Академія наук (Представництво в Києві), Інститут гідромеханіки Національної академії наук України, Академія будівництва України (Рис. 1).

До організаційного комітету увійшли голова конференції, ректор КНУБА Петро Куліков, заступник голови професор Михайло Сукач, почесний співголова, директор Представництва ПАН в Києві Генрик Собчук, керівник комісії з моторизації та енергетики Відділу ПАН в Любліні Еугеніуш Красовскі (Рис. 2).

Науковий комітет очолили його голова професор Михайло Сукач, віце-голова, проректор $з$ наукової роботи КНУБА Віталій Плоский, віце-голова, член-кореспондент ПАН Ян Гліньскі та професор Національного гірничого університету Всеволод Франчук.

Ідея форуму полягала в інтеграції українських, закордонних фахівців і наукових шкіл $з$ питань розробки теорії, проведення досліджень, створення нової техніки і методів, практичного застосування інноваційних енергоощадних та екологічно безпечних технологій. Головна мета конференції - аналіз та оцінка стану проблем в галузі підводних технологій, результати наукових i практичних досліджень, впровадження їх у виробництво.

3 вітальним словом до учасників конференції звернулись (Рис. 3) проректор з наукової роботи і міжнародних зв'язків профеcop Віталій Плоский, директор Представництва Польської академії наук в Києві професор Генрик Собчук, голова комісії 3 моторизації і енергетики відділу ПАН в Любліні професор Еугеніуш Красовскі, Президент Академії будівництва України Іван Назаренко.

Пленарне засідання розпочалося 3 виступу професора Київського національного університету будівництва i архітектури Михайла Сукача «Проблеми та перспективи розробки мінеральних ресурсів Світового океану». 
Робота МНПК «Підводні технології, 2015» відбувалася за шістьма напрямами, в яких розглядалися наступні питання.

1. Дослідження дна акваторій:

- характеристики морського і річкового дна - геодезія, картографія, геоінформаційні системи.

- методи і технічні засоби вивчення грунту - дослідні судна і підводні апарати

2. Видобування корисних копалин:

- методи і засоби розвідки родовищ

- технології видобування корисних копалин

- глибоководні грунторозробні машини

- транспортування і логістика.

3. Будівництво та прокладання комунікацій:

- днопоглиблювальні та очисні роботи

- бетонування і влаштування фундаментів

- конструкції та матеріали споруд

- підводні трубопроводи і лінії зв'язку.

4. Гідротехніка і обладнання:

- розробка та освоєння підземних вод

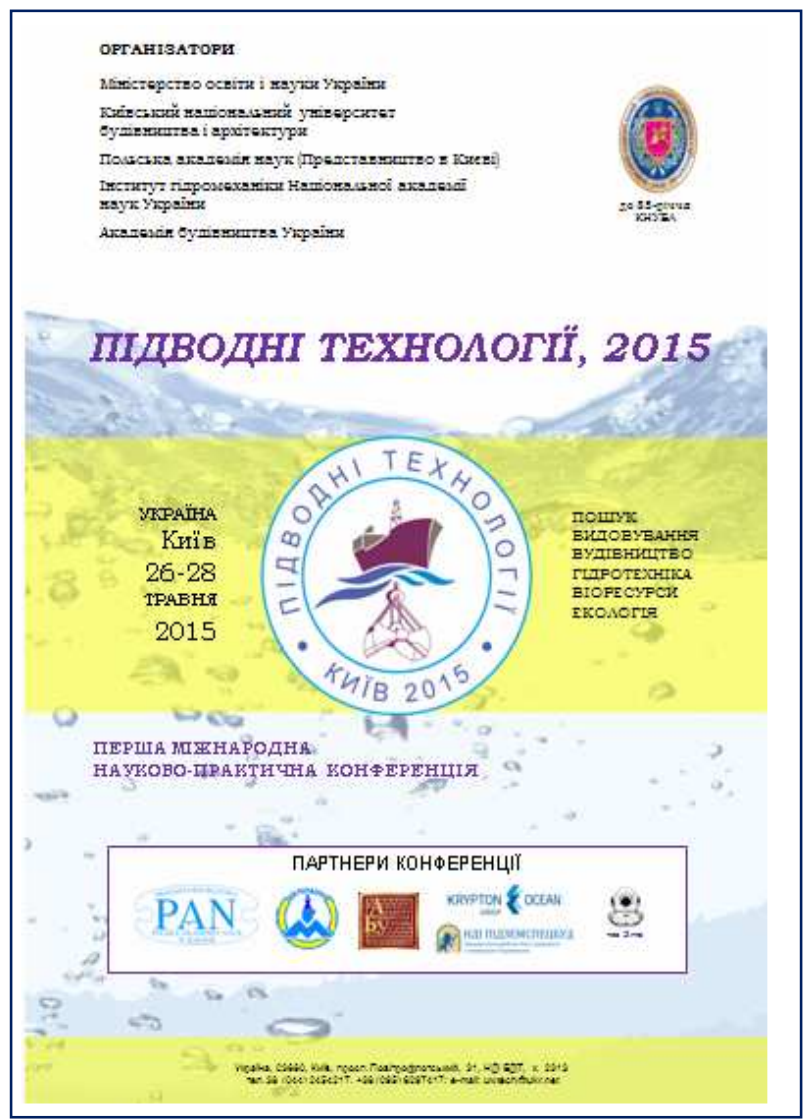

- водозабірні свердловини і обладнання

- рекультивація водонасичених грунтів.

5. Розробка та відновлення морських біоресурсів:

- морські промислові об'єкти

- знаряддя і технології вилову та збирання

- відтворення морських біоресурсів.

6. Безпечність робіт і екологія водного середовища:

- водолазне спорядження і мала механізація

- енергетичне та інформаційне забезпеченНя

- безпечність днопоглиблювальних робіт

- охорона середовища від забруднень.

Застосовано три форми участі у конференції:

очна, в якій учасники презентували свої доповіді та повідомлення;

$>$ заочна, із представленням результатів досліджень в галузі підводних технологій та опублікуванням у наукових фахових виданнях;

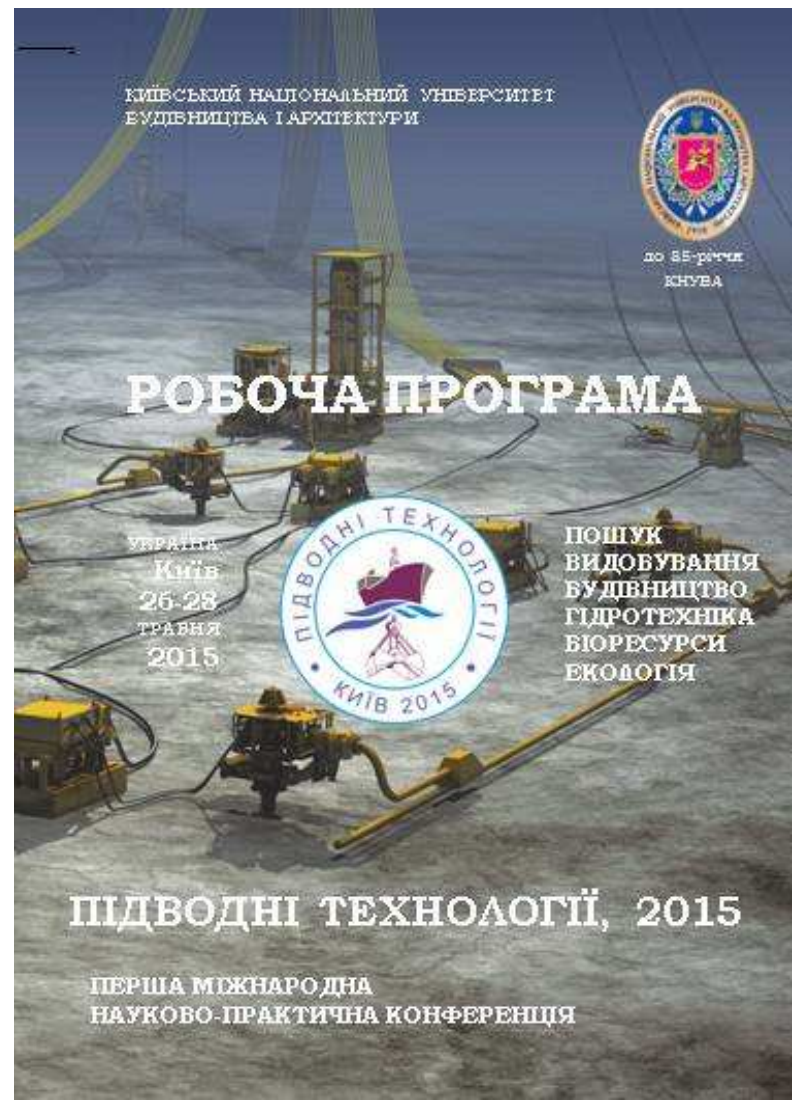

Рис. 1. Запрошення й робоча програма конференції

Fig. 1. Invitation and executable code of conference 

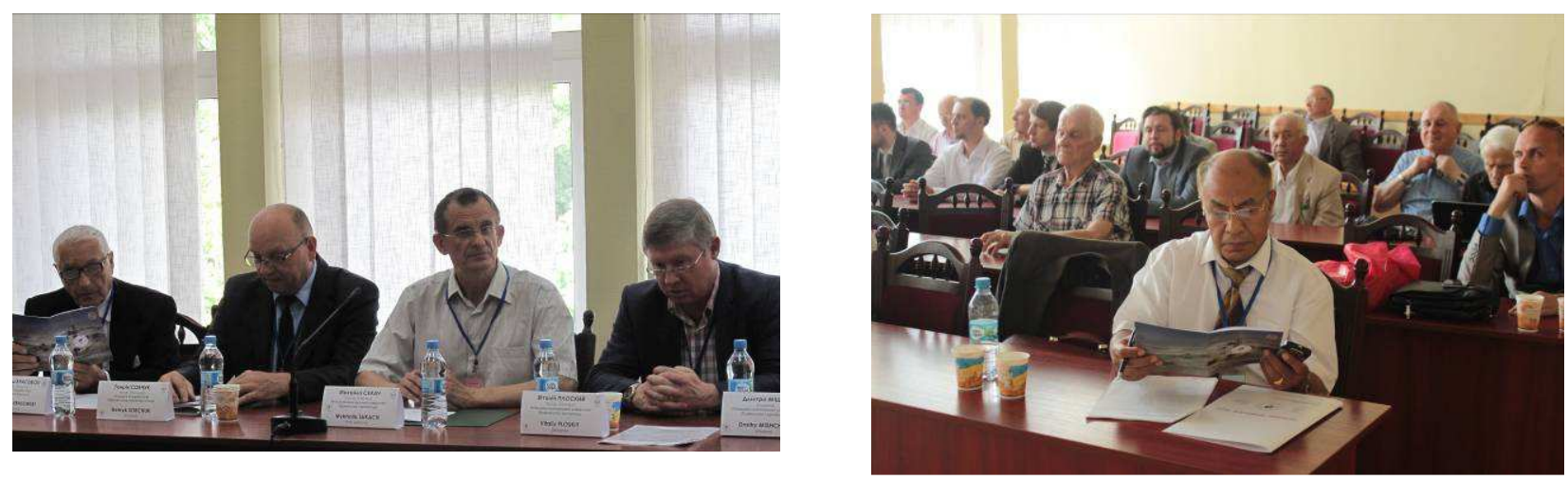

Рис. 2. Відкриття Першої Міжнародної науково-практичної конференції «Підводні технології, 2015»

Fig. 2. Opening of the First International scientifically-practical conference is «Unterwater Technologies, 2015»

в якості відвідувачів, яким було надано можливість надати рекламу та зразки своєї продукції, здійснити трансфер новітніх технологій за тематикою конференції.

Для обміну науковим досвідом до університету завітали представники 38 країн світу. Серед них науковці зі Швеції, Польщі, Китаю, Непалу, Ізраїлю, Угорщини, Латвії, Росії. Разом з українськими вченими вони представили результати свої наукових і практичних досліджень та впровадження їх у виробництво.

Під час подальшої роботи заслухано 9 пленарних і 35 секційних доповідей, розглянуто та обговорено 2 дисертації на здобуття наукового ступеню кандидата технічних наук, а також докторську дисертацію
Андрія Бондаренка «Наукове обгрунтування параметрів комплексів нового технічного рівня для гідромеханізованого видобутку й переробки зернистих корисних копалин», яку невдовзі після закінчення конференції успішно захищено на спеціалізованій вченій раді у ДВНЗ Національний гірничий університет (Дніпропетровськ).

В конференції прийняли участь вітчизняні та іноземні науковці, проектанти, виробники, бізнесмени, спостерігачі, а також студенти, магістранти й аспіранти 3 вищих навчальних закладів. Укладено декілька попередніх договорів про наміри по співробітництву, налагоджено ділові контакти та зв' язки.

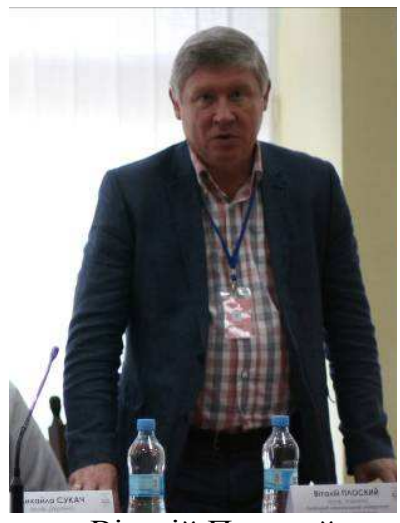

Віталій Плоский

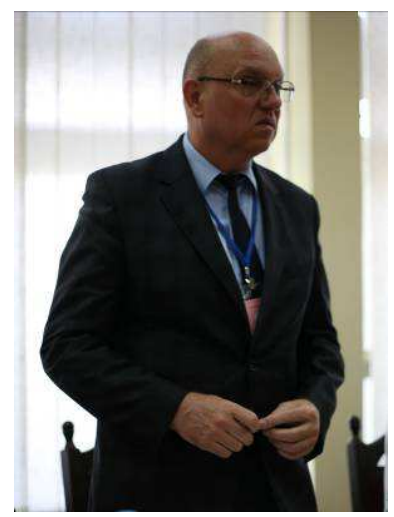

Генрик Собчук

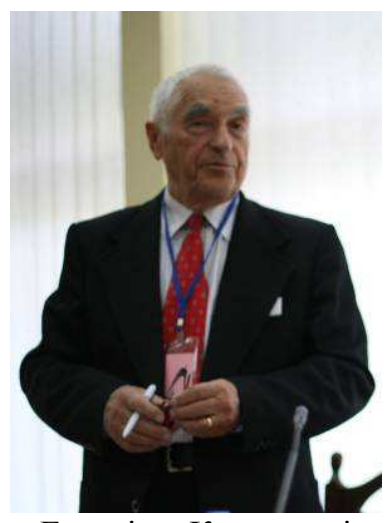

Еугеніуш Красовські

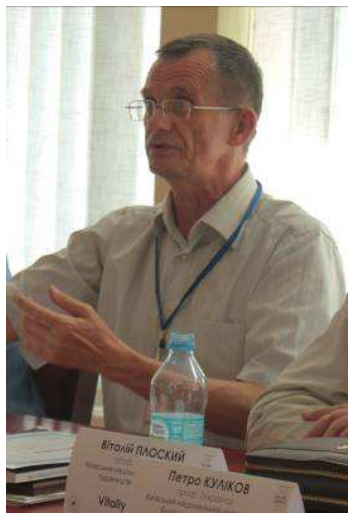

Михайло Сукач

Рис. 3. На пленарному засіданні

Fig. 3. On plenary meeting 
Перше секційне засідання відкрилося повідомленням професорів Петра Кулікова і Михайла Сукача «Про готовність України до вступу в Міжнародний консорціум з розробки та освоєння копалин Світового океану». Учасники конференції відтворили широку гаму проблем, специфіку й складність тематики форуму, сприяли продовженню досліджень, відтворенню та актуалізації розглядуваних питань 3 підводних технологій (Рис. 4).

Насамперед, це професори Володимир Гришин, Володимир Снісаренко, директор НДІ Підземспецбуд Лев Гембарський, які надали слушну інформацію про «Деякі аспекти затоплення конструкцій новозведеного хвилелома в акваторії одеського пор-

ту», а також про «Існуючі й проектовані штучні острови та їх призначення».

В доповіді «Мобільні споруди в береговій гідротехніці» старшого наукового співробітника Інституту гідромеханіки НАН України Свгена Горбатенко, Ірини Братасюк та директора ТОВ П'ятого гідротехнічного підводного загону Володимира Шарова зазначено специфіку їх використання, основні задачі вдосконалення берегового захисту як у плані природоохорони в цілому, так і в сенсі виконання підводно-технічних робіт під час монтажу-демонтажу мобільних наносорегулювальних споруд.

Представник Міжнародної компанії «Криптон Океан Груп» Владислав Квятковський презентував «Розробку й використання підводного транспортного модуля для глибоководного видобування корисних копалин». В ній було представлено технологію і технічні засоби, що дозволяють приступити до будівництва перших підводних транспортних модулів, які будуть використовуватись для глибоководного видобування поліметалевих ресурсів Світового океану.

Завідувач відділу електропружності Інституту механіки НАН України проф. Олександр Безверхий та ст.н.с. Вікторія Корнієнко надали дві доповіді «Динаміка підводних розгалужених буксируваних тросових систем», «Коливання тросових систем з нелінійно-пружними характеристиками». В них було розглянуто динаміку і параметри коливань тросових елементів розгалужених конструкцій 3 урахуванням нелінійнопружних характеристик матеріалів окремих елементів в умовах розвинутого морського хвилювання.

Доктор Кришна Каястха із Непалу в доповіді «Застосування свердловин 3 гравійно-парасольковим фільтром поширеного контуру» представив новий тип водозабірної свердловини, а також результати проведених досліджень 3 використанням фізичного і електричного моделювання в польових умовах. Професор Григорій Іванченко (КНУБА) звернув увагу на «Критичний стан взаємодії хвилі сильних розривів у воді 3 пружним екраном». Використовуючи нульове наближення променевого методу, чисельно досліджено перебудову геометрії сферичних фронтів підводної хвилі сильних розривів та зміну імпульсу, що переноситься ними, при подоланні хвилею пружного екрану.

Актуальними є представлені на конференції з підводних технологій «Пропозиції про відтворення Дунайсько-Чорноморської ліхтеровозної системи» (доповідачі директор компанії «ПРОІНФО» Андрій Дмитренко та представник Міжнародного господарського суднохідного підприємства «Інтерліхтер» Юлія Ульяновська з Угорщини), а також презентація технології намивання та спорудження штучних островів і портових споруд (на прикладі таможні в морі: Саудівська Аравія - Бахрейн).

Сміливу і наповнену технічними складностями подано ідею професора Миколи Жука, Мирона Назаряна (Славяно-Арійська академія) та к.т.н. Юрія Стельмахова (МНГЕО Інтер-Чорнобиль) щодо будівництва «Великого Шовкового шляху в суднохідному варіанті» 3 Китаю до Європи у вигляді комплексу гідротехнічних споруд, включаючи судноплавні канали від Китаю до Каспійського моря і від Каспійського до Чорного моря з тунелем під хребцем Кавказу.

Футуристичними і надзвичайно цікавими були презентації студентів і магістрантів з Національного транспортного університету Ганни Чорнобай, Олександра Городецького та Віктора Загривого, а також Ро- 


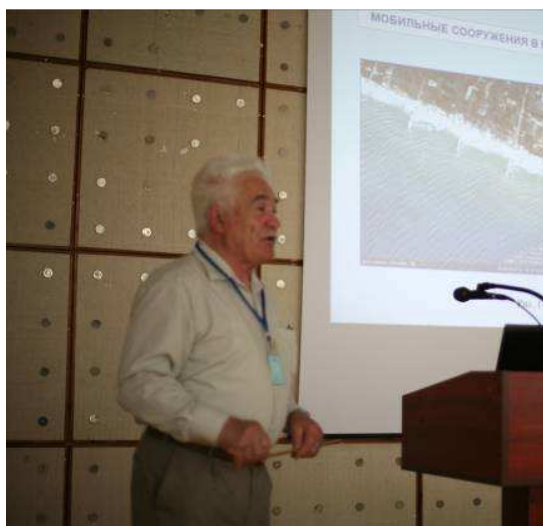

Євген Горбатенко

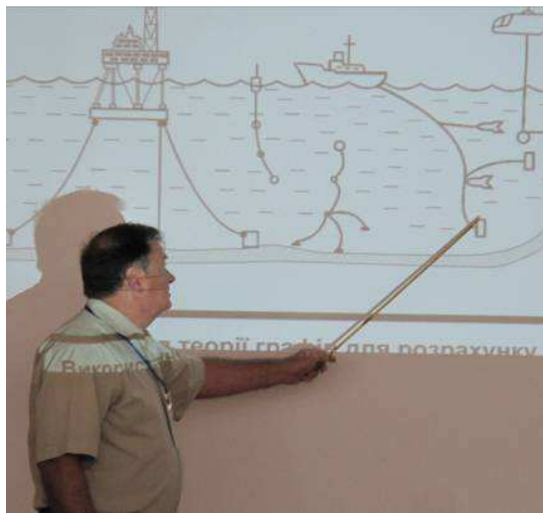

Олександр Безверхий

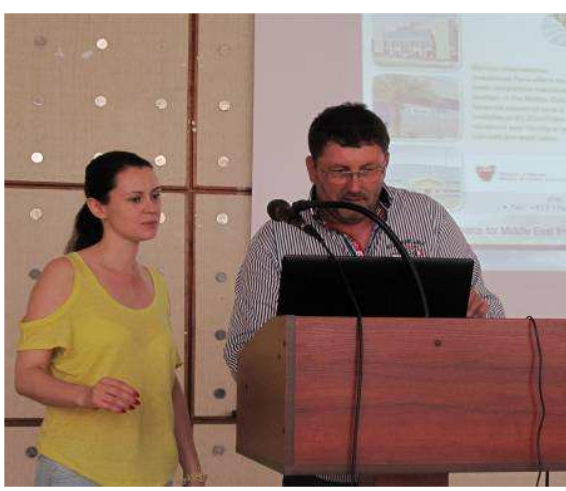

Юлія Ульяновська,

Андрій Дмитренко

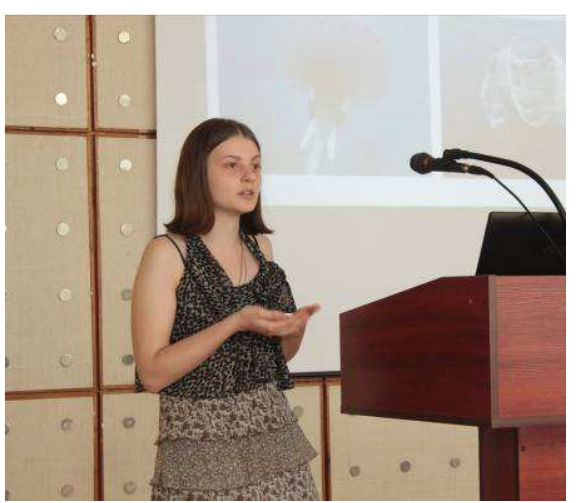

Ганна Чорнобай

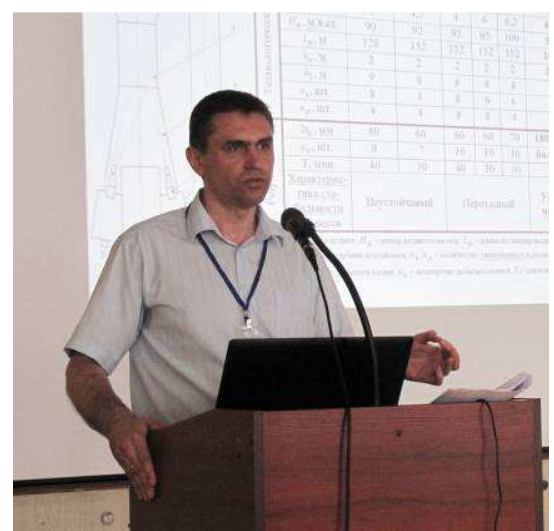

Андрій Бондаренко

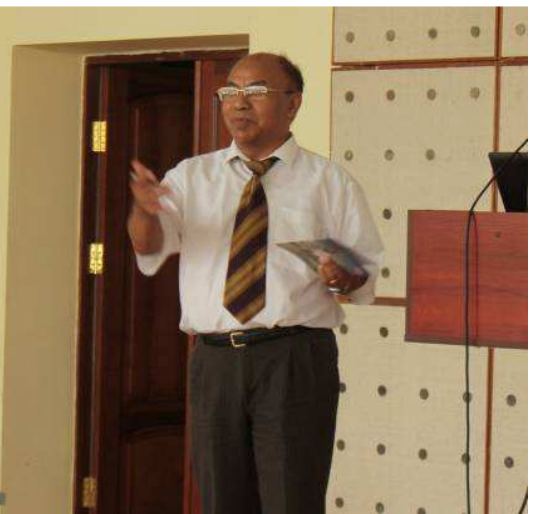

Кришна Каястха

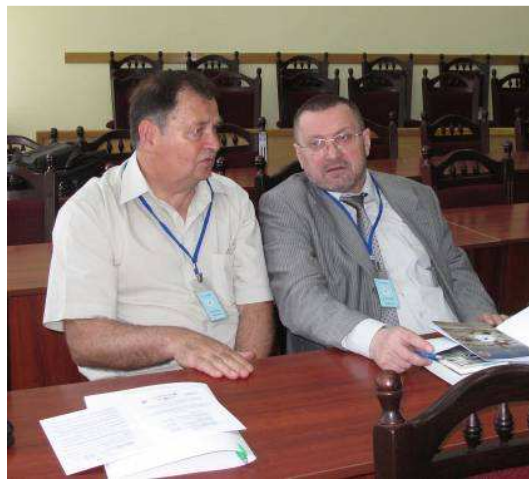

Олександр Трофимчук (праворуч)

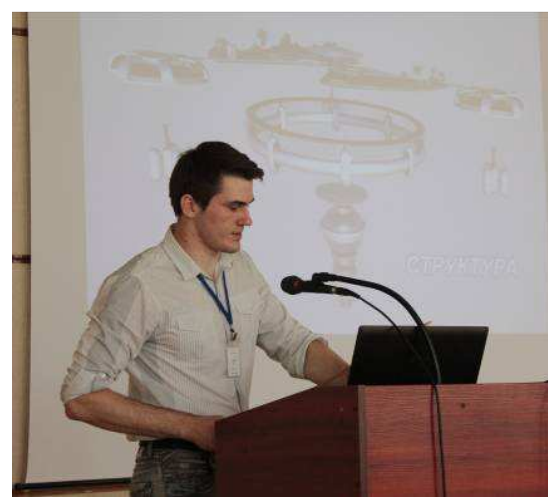

Віктор Загривий

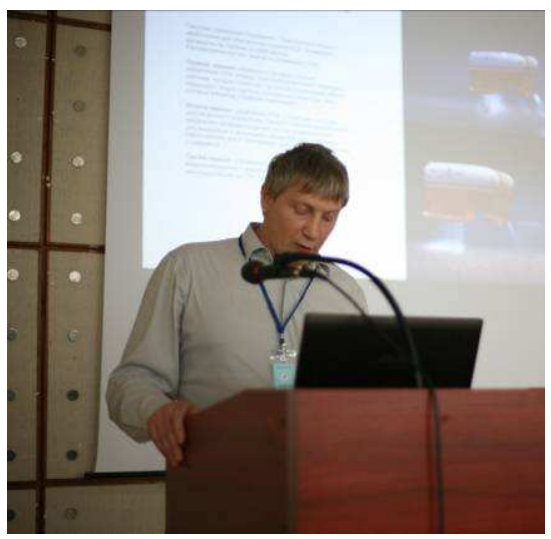

Владислав Квятківський

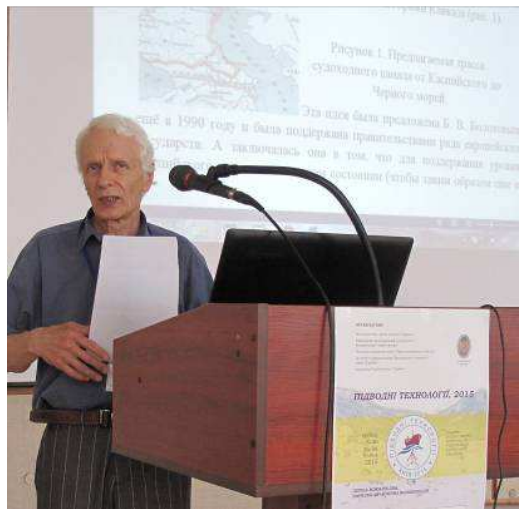

Юрій Стельмахов

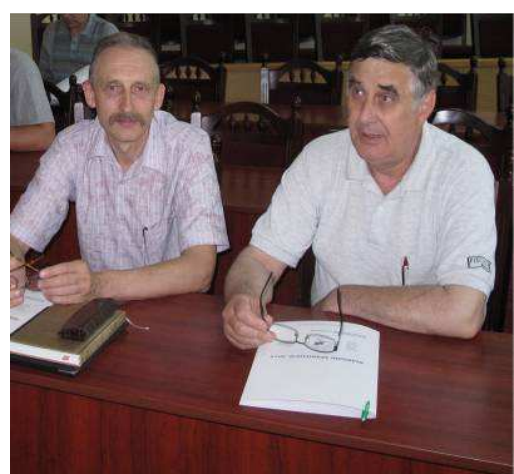

Григорій Іванченко, Олександр Вольтерс

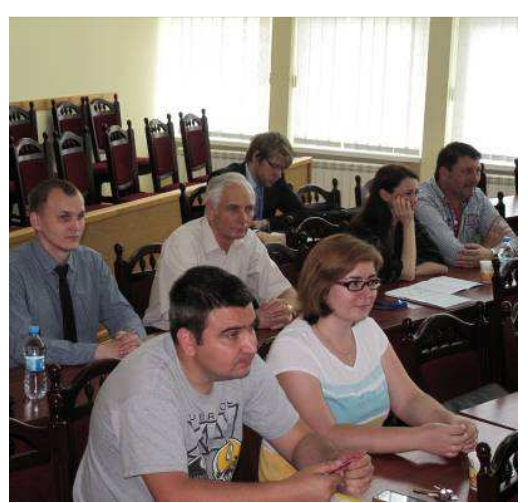

Відвідувачі конференції

Рис. 4. Перше секційне засідання

Fig. 4. First sectional meeting 
мана Федорончука (ПАТ ДАК «Автомобільні дороги України), які продемонстрували низку проектів майбутнього: «Екологічний комплекс для очищення водного простору», «Футуродизайн плавучого науководослідницького центру екології та гідробіології», «Моделювання методу та робочого обладнання для підсилення основ транспортних споруд в умовах перезволожених грунтів».

Професор Роман Шульц 3 групою співавторів (Владиславом Павлоцьким, Олегом Телендієм, Павлом Старжинським, КНУБА) окреслили «Сучасний підхід до створення цифрових моделей дна внутрішніх водойм» та «Перспективи застосування лідарної батіметрії». Науковці Національного університету біоресурсів і природокористування професор Валерій Войтюк та доцент Іван Роговський розповіли про «Технічні засоби інформаційного забезпечення водного середовища в агропромисловому комплексі». Дмитро Кокарєв і Леонід Ройберман представили «Енергоощадні технології підігріву води від ізраїльської компанії «Амкортек».

Заслухано доповіді представників Відкритого міжнародного університету розвитку людини «Україна» професора Віктора Малишева, доцента Валерія Косенка, Ніни Кущевської «Жароміцні композиції на основі нанопорошкових силікатів тугоплавких металів для підводних конструкцій», «Корозійностійкі матеріали для пристроїв та обладнання, що працюють у хімічноактивному середовищі». Максим Кушнарьов та Геннадій Тонкачеєв (КНУБА) розповіли про «Технологію влаштування монолітних стін у ковзній нерухомій опалубці», а Іван Назаренко, Анатолій Свідерський, Микола Ручинський та Олег Дєдов (КНУБА) - про «Наукові основи створення вібраційних систем з гідроприводом».

Цікавою інформацією про «Використання двигуна Стірлінга для промислового глибоководного видобування поліметалевих конкрецій в океані» поділився студент КНУБА Микита Мельниченко (керівники доценти Ігор Космінський та Юрій Баранов). Студенти Тетяна Погребняк, Яна Луценко і Вадим Печерський під керівництвом Миколи Клименко розглянули «Особ- ливості приготування будівельних сумішей та виконання бетонних робіт при зведенні бетонних конструкцій під водою», а також «Призначення присадок підшипників кочення важко навантажених вузлів, що працюють в складних умовах при проведенні підводних робіт».

На засіданні другої секції представлено низку доповідей, презентацій і повідомлень 3 питань розробки, проектування, випробування, досліджень та впровадження нової техніки і технологій (Рис. 5). Так, асистент Олександр Марченко і Світлана Комоцька (науковий керівник професор Михайло Сукач) розробили проект «Безтраншейного прокладання кабелів по дну протяжних водних об'єктів» та «Технології й обладнання для будівництва кабельних ліній по дну водоймищ».

Студенти Київського національного університету будівництва і архітектури Станіслав Лаврик і Микола Карпенко на чолі 3 професором Леонідом Пелевіним представили доповіді про «Особливості роботи бульдозерів з віброзбудником при гідростатичному навантаженні» й «Розробку шельфів динамічними робочими органами». Доценти Свген Горбатюк та Володимир Волянюк разом зі студентом Артемом Владом обгрунтували «Математичні моделі рельєфу при взаємодії рушія будівельно-дорожніх машин 3 поверхнею грунту в прибережних зонах водоймищ».

Науковий секретар конференції Дмитро Міщук виконав «Кінематичне дослідження робочих рухів будівельного робота при проведенні підводних робіт», доценти Олександр Вольтерс, Василь Головань, Вячеслав Смірнов проаналізували «Обладнання для створення опор гідротехнічних споруд», Тетяна Щербина запропонувала «Використання вібраційних машин під час проведення підводно-технічних робіт».

Роботу Григорія Мачишина «Фінішна обробка гребних гвинтів полімерноабразивними щітками» (науковий керівник професор Юрій Абрашкевич) на конференції було схвалено та через місяць потому захищено на засіданні вченої ради Д 26.056.08 при КНУБА й присуджено здобувачеві науковий ступінь кандидата техніч- 


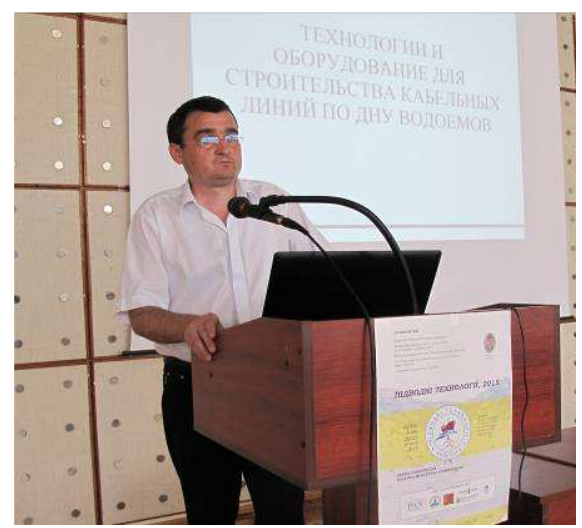

Олександр Марченко

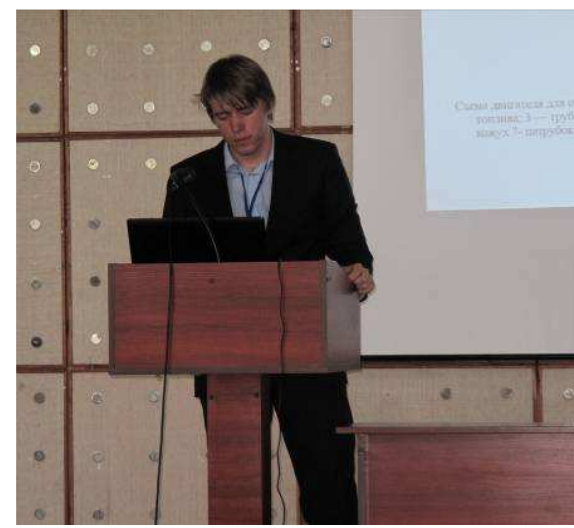

Микита Мельниченко

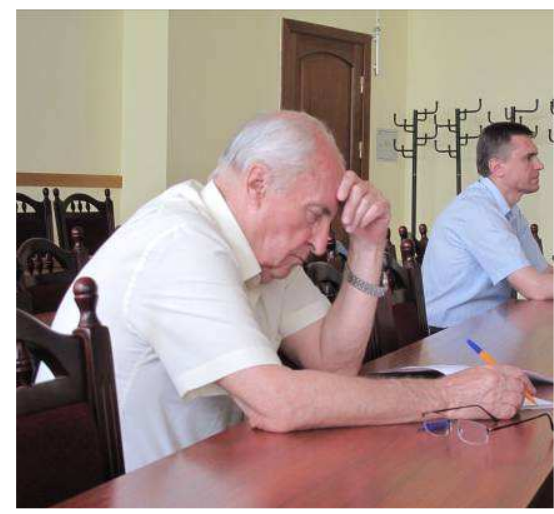

Юрій Абрашкевич

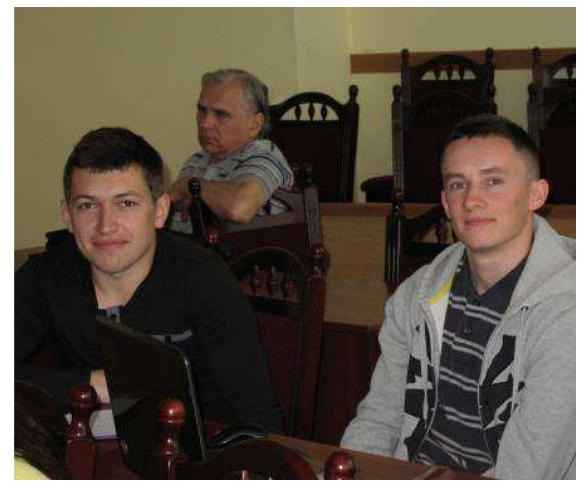

Олександр Костенюк зі студентами

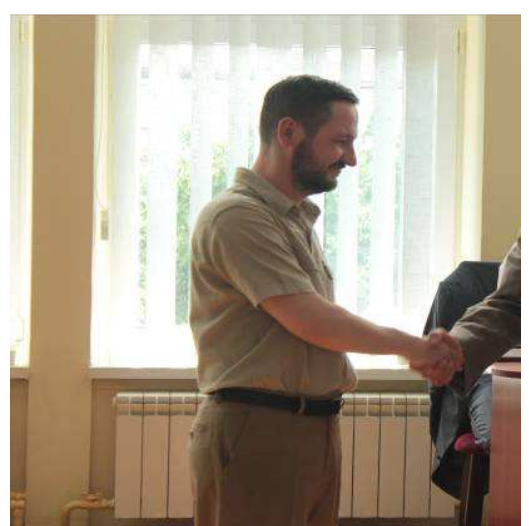

Євген Горбатюк

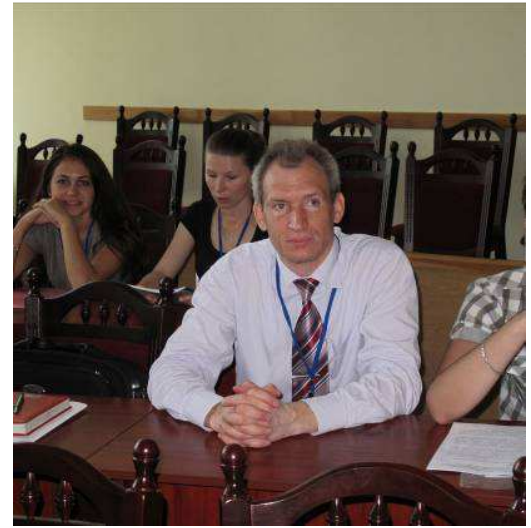

Микола Клименко

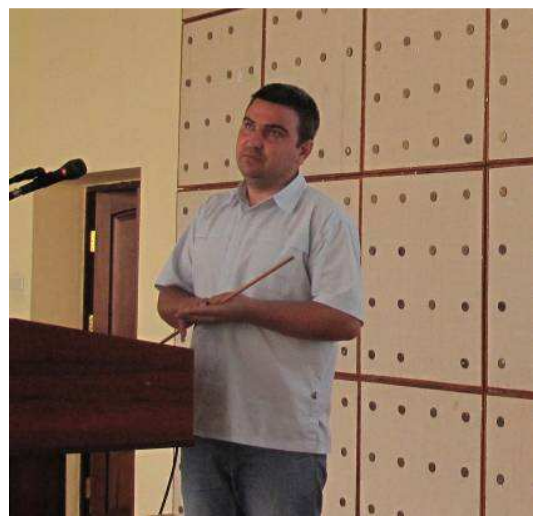

Григорій Мачишин

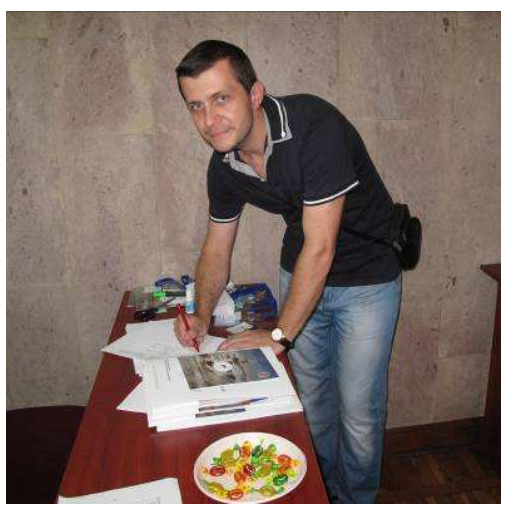

Максим Балака

Рис. 5. Друге секційне засідання

Fig. 5. Second sectional meeting

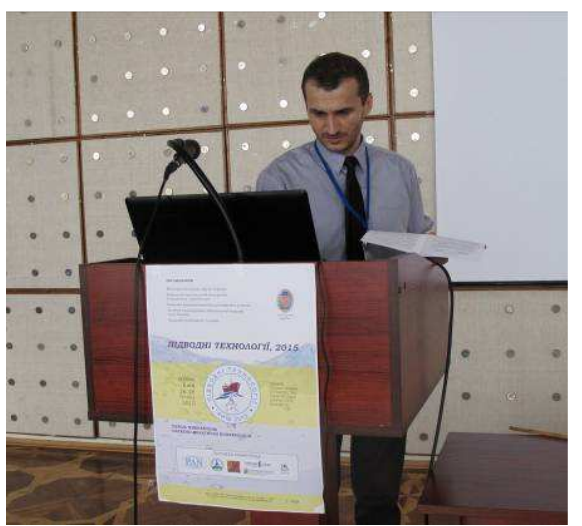

Дмитро Міщук

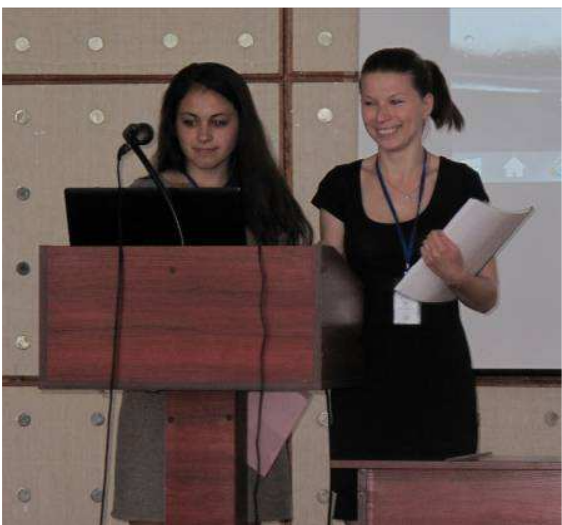

Тетяна Погребняк, Яна Луценко

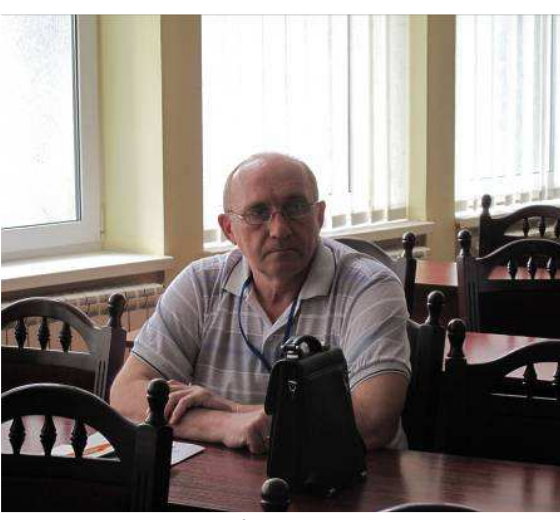

Геннадій Тонкачеєв

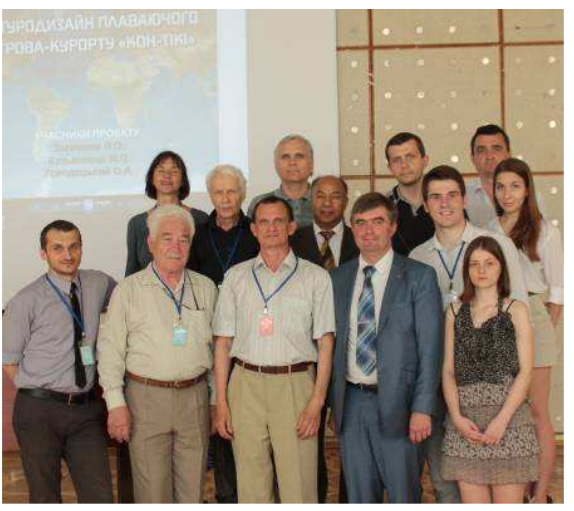

Фото на згадку

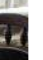


них наук. Матеріали дослідження Олександра Тетерятника і Олександра Костенюка «Доцільність використання конусної фрези під час проведення підводних робіт» рекомендовано до виробничої апробації.

Професор Анатолій Фомін разом зі співавторами Олександром Костенюком, Тарасом Мартинюком, Олександром Тетерятником представили доповіді про «Зменшення опорів грунту зубу розпушника в режимі заглиблення робочого органу при розробці прибережних грунтів», «Підвищення ефективності розробки міцних матеріалів алмазними робочими органами в підводних умовах», «Динамічне руйнування підводних грунтів 3 керуванням потоками енергії у просторі й часі».

Доцент Володимир Рашківський та магістрант Микола Карпенко опікувалися «Технологічними особливостями механізованого руйнування підводних грунтів глибоководних озер» та «Використанням гідравлічного ударного молота для руйнування ущільнених шарів грунту під водою», а доценти Микола Пристайло й Микола Кузьмінець - «Тривимірним моделюванням навантажень на металоконструкцію та робочим обладнанням плавучих засобів для розробки підводних грунтів». Доцент Олег Марков (Національний транспортний університет) виклав «Теоретико-методологічні основи сфери сервісу технічних систем».

Низка доповідей стосувалася питань екології підводних робіт, це: «Методи очищення стічних вод нафтогазовидобувної промисловості», «Безпечність робіт і екологія водного середовища» асистентів Максима Балаки та Вячеслава Слободчикова, «Обладнання для очищення берегової лінії» й «Особливості охорони праці та безпеки життєдіяльності при роботі з водолазним спорядженням» авторів Олексія Москаленко, Олександра Тетерятника, Володимира Холявки.

Під час проведення конференції учасникам було надано можливість презентації своїх розробок, демонстрації зразків нової техніки, а також місце й час для реклами інноваційних технологій, залучення фахівців до переговорів, укладання двосторонніх i багатосторонніх угод про співпрацю, у тому числі міжнародних стосунків, демонстрації фахових та опублікованих видань (Рис. 6).

Відбулося нагородження Великою срібною медаллю Академії будівництва України переможців конкурсу в номінації «За кращу опубліковану роботу в галузі будівельної науки» 2014 року, яких привітав Президент АБУ академік Іван Назаренко.

За результатами роботи конференції 55 учасників відзначено персональними сертифікатами Першої МНПК «Підводні технології, 2015», про що розміщено повідомлення на університетському сайті www.knuba.edu.ua.

Роботу конкурсної комісії очолював член-кореспондент НАН України, заступник директора 3 наукової роботи Інституту телекомунікацій і глобального інформаційного простору професор Олександр Трофимчук. Переможцями конкурсу на кращу студентську науково-практичну роботу в 2015 році визнано команду Національного транспортного університету під керівництвом завідувача кафедри комп'ютерної, інженерної графіки та дизайну Миколи Кузьмінця.

3 огляду на виявлений інтерес та актуальність проблематики конференції, а також 3 метою висвітлення інноваційних технологій в галузі запропоновано заснувати новий Міжнародний науково-виробничий журнал «Підводні технології: промислова та цивільна інженерія» (адреса для листування: uwtech@ukr.net, правила оформлення статей розміщено на сайті КНУБА).

До складу редакційної колегії увійшли доктори, професори з 20 вітчизняних і 6 закордонних університетів Німеччини, Польщі, Китаю, Білорусі та ін.; наукові співробітники 6 Інститутів Національної академії наук України, 3 галузевих Академій, представники 2 наукових закладів Польської академії наук; керівники та провідні фахівці з 9 вітчизняних і 12 закордонних науково-дослідних і виробничих організацій.

Кращі доповіді й презентації, представлені на конференції, рекомендовано до публікації у першому та другому випусках журналу «Підводні технології» у 2015 році. 


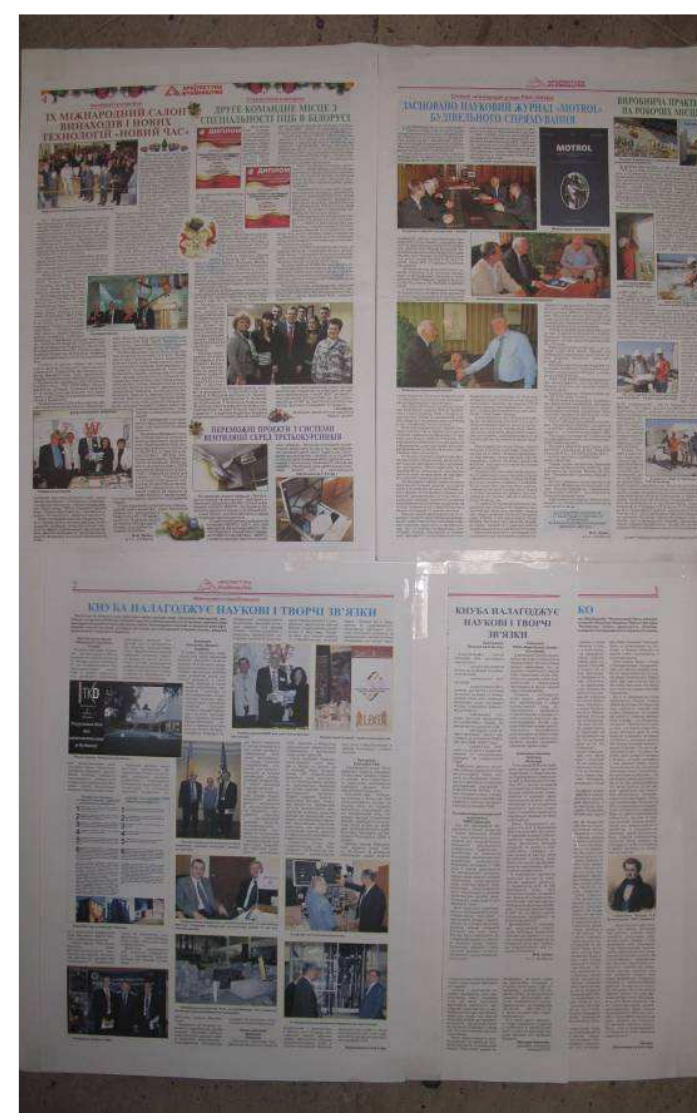

Міжнародні стосунки науковців

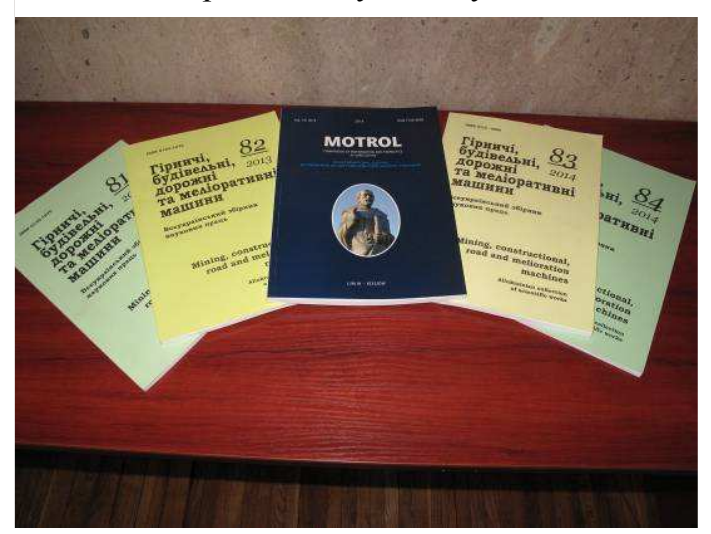

Спільні фахові видання
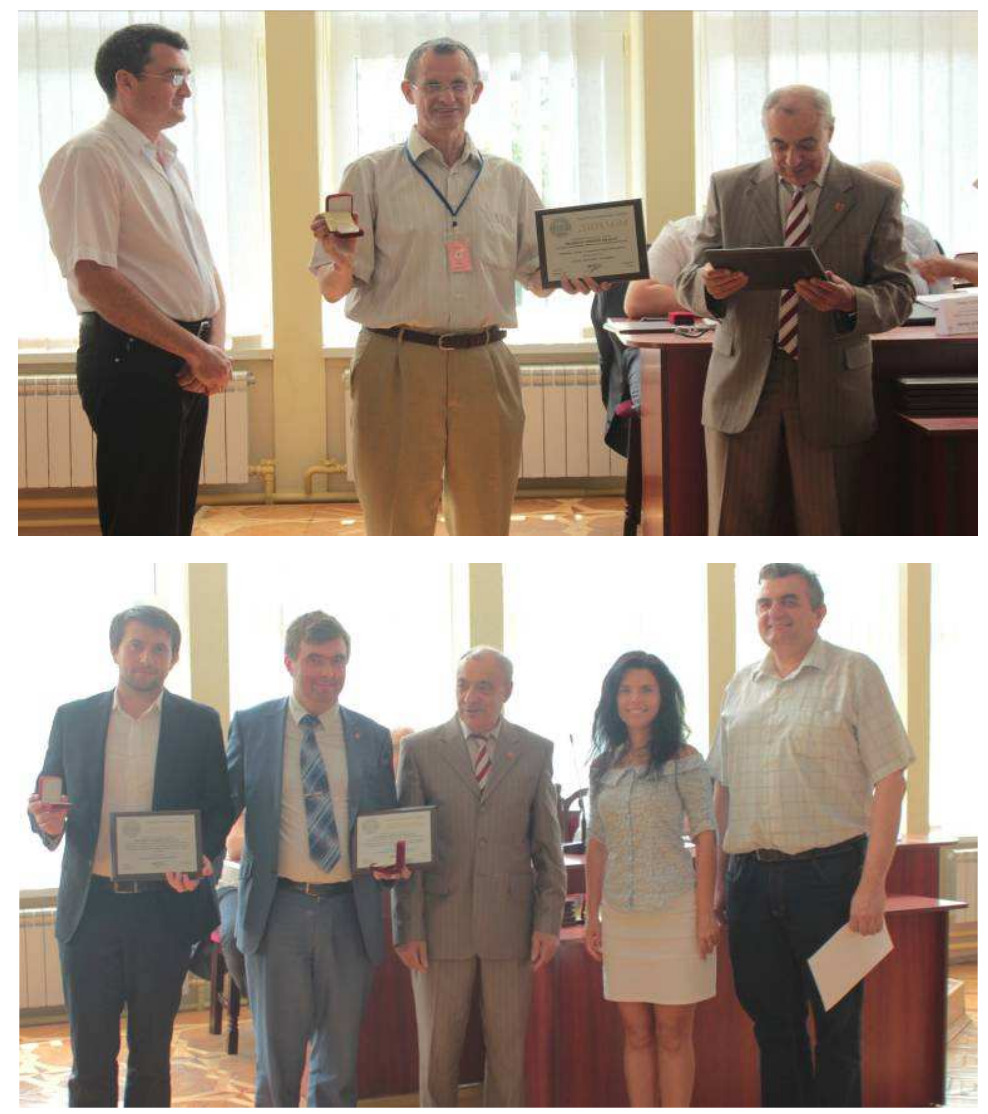

Переможці конкурсу «За кращу опубліковану роботу»
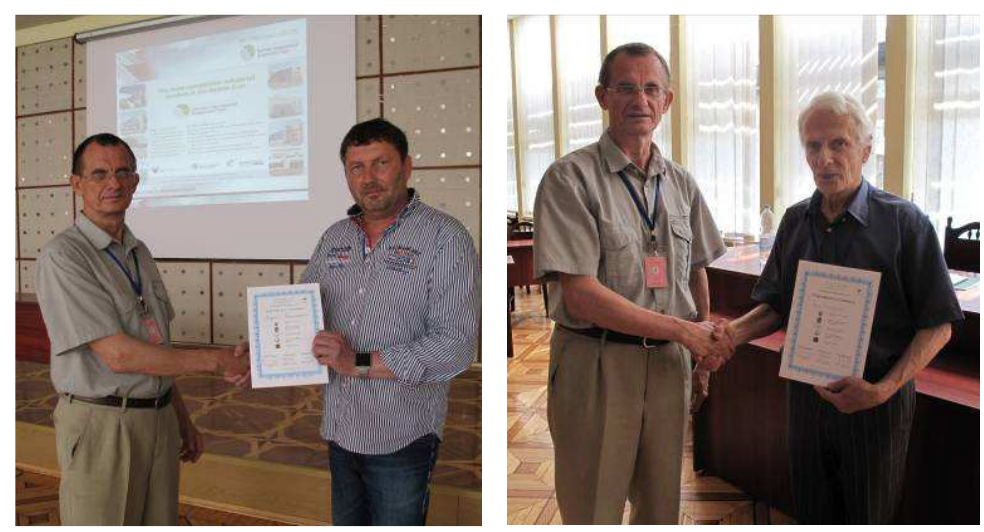

Сертифікати учасника МНПК «Підводні технології, 2015»

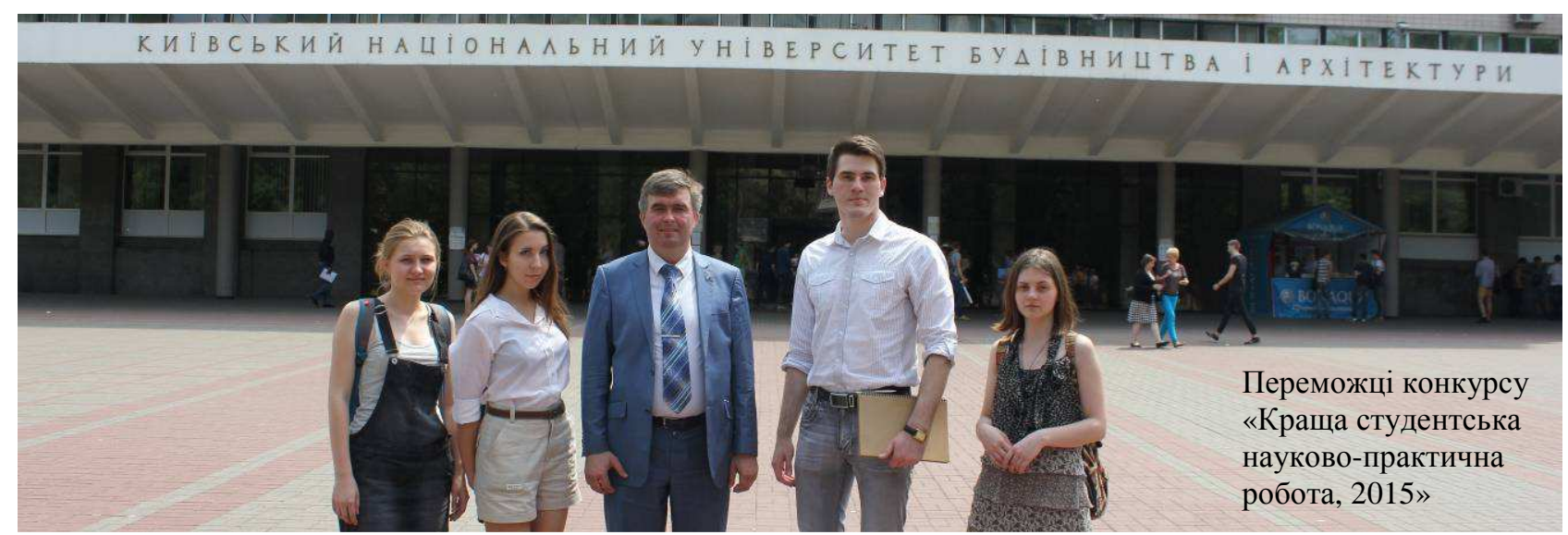

Рис. 6. Підсумки роботи конференції

Fig. 6. Balances of the work of conference 
Водночас маємо можливість розмістити статті у двох міжнародних англомовних журналах Motrol i Teka Польської академії наук (www.pan-ol.lublin.pl/wydawnictwa/ Teka-Motrol.html), інтегрованих у Skopus. Матеріали до них приймаються за адресою motrol@ukr.net.

3 огляду на виявлену зацікавленість й активність учасників, прийнято рішення про підготовку Другої Міжнародної науково-практичної конференції «Підводні технології, 2016» та розширення кола розглядуваних питань.

Оголошено конкурс на кращу науковопрактичну роботу в галузі підводних технологій за категоріями «Кращий проект», «Краща презентація», «Краща публікація», серед студентів i фахівців. Розглядаємо оригінальні ідеї, дослухаємось до нестандартних і сміливих рішень. Підтримуємо нові пропозиції та креативні думки!
Організаційний та науковий комітети конференції висловлюють щиру подяку доповідачам, відвідувачам, спонсорам, зокрема ректору КНУБА Петру Кулікову, який надав приміщення для роботи нашого форуму, проректорі Віталію Плоскому - за сучасну оргтехніку і корисні поради, почесному співголові конференції Генрику Собчуку - директору Представництва Польської Академії наук в Києві, який прийняв активну участь в організації заходу, Владиславу Квятківському - представнику Міжнародної компанії «Криптон Океан Груп» за фінансову підтримку.

Дякуємо усім партнерам Першої Міжнародної науково-практичної конференції «Підводні технології, 2015», які надали посильну допомогу, полегшили іi організацію й проведення, а також секретарям конференції Дмитру Міщуку, Світлані Комоцькій та іншим добродіям, які спряли розповсюдженню інформації про неї та залученню нових учасників. 